Firma neoPR

\title{
Kampania wyborcza na fotelu prezydenckim - skuteczne metody zarządzania informacją w mieście
}

\section{Wstęp}

K luczem do wygranej kampanii wyborczej jest umiejętne dotarcie - z informacją do wyborców. Tą informacją są hasła, programy czy podsumowanie swojej dotychczasowej pracy. W dobie globalizacji i przy stałym rozwoju internetu nie wystarczy już bezpośredni kontakt czy tradycyjne narzędzia public relations. Ostatnie piętnaście lat przyniosło ze sobą ogromne zmiany. Najbardziej oczywistą z nich jest powstanie wyszukiwarki Google i serwisu społecznościowego Facebook, który umocnił przekonanie, że komunikacja za pomocą kontaktów personalnych - wiadomości przekazywanych z ust do ust, czyli tzw. poczta pantoflowa - stała się znacznie bardziej skuteczna niż kiedyś. Przed nastąpieniem ery internetu, podmioty, które chciały zdobyć zainteresowanie osób trzecich, miały do wyboru jedynie dwa sposoby postępowania: zakup kosztownej reklamy lub przekonanie mediów do poświęcenia im artykułu, programu telewizyjnego itp.

Popularność sieci zmieniła zasady gry. Internet to nie telewizja. Podmioty, które rozumieją nowe zasady działań public relations, nawiązują bezpośrednie relacje $\mathrm{z}$ klientami, wyborcami czy konsumentami ${ }^{1}$. Internet sprawił, że PR, po latach koncentrowania się niemal wyłącznie na mediach, znowu jest dziedziną skierowaną do publiki. Publiki, która jest jednak znacznie bardziej wymagająca. Dlatego marketing internetowy nie przeszkadza dziś odbiorcy. Polega na dostarczaniu użytecznych treści dokładnie w tym momencie, w którym nabywca ich potrzebuje.

Ale to nie wszystko. Dziś wyborcy już nie tylko oczekują rzetelnej i merytorycznej informacji. Potrzebują także rozrywki oraz elementów

1 D. Meerman Scott, Nowe zasady marketingu i PR, Warszawa 2009, s. 13-35. 
angażowania. Dodatkowo zupełną nowością w komunikacji w internecie jest jej interaktywność. Odbiorca wiadomości to już nie bierny uczestnik procesu komunikacji, ale aktywny nadawca, który na bieżąco udziela nam i pozostałym uczestnikom informacji zwrotnej.

\section{Rola nowych mediów w kampanii wyborczej}

Media społecznościowe jeszcze do niedawna wydawały się jedynie bezproduktywnymi ,zjadaczami czasu” użytkowników internetu. Dziś mówi się o nich, że są to serwisy skierowane do konkretnej grupy społecznej, które pozwalają na dużą ingerencję użytkowników w ich treść i charakter, dając każdemu możliwość prawdziwej, dwustronnej komunikacji z niemalże całym światem. Jedynym warunkiem, by chciano z nami rozmawiać, jest to, żebyśmy mieli coś ciekawego do powiedzenia.

Rola mediów społecznościowych jest ogromna, z dnia na dzień pojawiają się kolejne powody ich popularności. Według badania, które wykonały firmy Synovate i Gemius, na zlecenie Hypermedia okazało się, że serwisy te służą głównie do komunikacji między użytkownikami. Wymiana informacji odbywa się zazwyczaj w kręgu znajomych ${ }^{2}$. Można zatem stwierdzić, że serwis społecznościowy jest systemem wspierającym kontakty ze świata rzeczywistego, a także umożliwia wysyłanie informacji o charakterze bardzo nieformalnym, takim jak: uśmiech w postaci komentarza na profilu, który jest tylko sygnałem chęci nawiązania lub podtrzymania relacji na odległość bez potrzeby prowadzenia rzeczowej konwersacji. Co ważne, jest to komunikacja dwustronna - wiele osób może ze sobą jednocześnie korespondować. Wcześniej taka forma dialogu była nieosiągalna na taką skalę.

Zjawisko powstania serwisów Web 2.0 spowodowało więc powstanie „nowego stylu komunikacji, do języka mówionego i pisanego dołączył «język społecznościowy», który jak się wydaje, zapełnił pewną lukę w komunikacji internetowej z zakresu budowania relacji międzyludzkich"3.

W Polsce zdecydowana większość internatów to członkowie społeczności. „80\% użytkowników potwierdza, że odwiedziło serwis społecz-

2 J. Rzepecki, G. Hankus-Matuszek, Wymagajacy użytkownik - bezcenny, „Marketing w praktyce” 2009, nr 8 (138) s. 38.

3 Ibidem, s. 38. 
nościowy, blisko $66 \%$ ma założony profil i prawie 50\% członków społeczności zagląda nań codziennie lub prawie codziennie. 16\% włącza komputer by wejść na swój ulubiony serwis (wg badania „Siła relacji, czyli potencjał społeczności interaktywnych w komunikacji marketingowej", zrealizowanego przez Gemius i Synovate na zlecenie Hypermedia w 2008 r.). W zestawieniu z wynikami zasięgu naszej-klasy pozwala to postawić znak równości między wszystkimi internautami a członkami społeczności w Polsce" 4 .

Oznacza to zupełną zmianę w realizacji kampanii marketingowych i komunikacyjnych. Politycy i placówki rządowe oraz samorządowe, mając taką skuteczną i natychmiastową okazję dodarcia z informacją do obywateli, nie mogą pozostać w tyle. Są zmuszeni korzystać z nowoczesnych narzędzi. Dziś już nie wystarczy zorganizować doskonałą konferencję prasową i wysłać komunikat prasowy na szablonowej kartce A4, czekając na upublicznienie przekazanych treści. Dziś władze - nie muszą używać tradycyjnych mediów - jako pośrednika w dotarciu do odbiorców. Co więcej nie tylko same mogą nadawać komunikat, ale dodatkowo uzyskują natychmiastowy feedback na przekazaną informację. Obustronność komunikacji i jej interaktywność to zupełnie nowy wymiar zarządzania informacją.

Kampania wyborcza jest doskonałą okazją do wykorzystania nowych mediów do promocji kandydata i zaangażowania obywateli do wspólnego kreowania zmiany społeczności, w której żyją. Wzorcowym przykładem wykorzystania mediów społecznościowych jest kampania wyborcza Baracka Obamy z 2008 r., która nie tylko okazała się skuteczna i znakomicie przeprowadzona, ale przede wszystkim zrewolucjonizowała marketing polityczny, używając nowych mediów do komunikowania się z wyborcami. Od samego początku celem kampanii B. Obamy było budowanie świadomości, pomocy oraz wsparcia wśród elektoratu. W tym celu zaangażowano sztab około 170 osób, w tym kilkuosobowy zespół analityków z firmy Google 5 . Wśród głównych kanałów komunikacji online wykorzystano m.in. Twitter, Facebook, Flickr, You Tube, a także komunikację poprzez email i kampanie reklamowe w formie display.

4 Ibidem, s. 37.

5 Sławek, Kampania Obamy. Efektywność działań online w liczbach, http://www.benhauer.pl/blog/kampania-baracka-obamy-w-internecie-podsumowanie/, 25.01.2011 r. 
Niewątpliwie działania sztabu wyborczego B. Obamy inspirują dziś polskich polityków. Można było to zaobserwować podczas ostatniej kampanii prezydenckiej czy parlamentarnej. Doskonałym na to przykładem jest kampania kandydata na europosła Rafała Trzaskowskiego, który wykorzystał do swoich działan kanał YouTube. Nagranie ciekawych i zabawnych spotów z udziałem znanych i cenionych osób ze świata publicznego jak np. Michał Żebrowski, Tomasz Karolak czy Piotr Adamczyk, wzbogaconych utworzeniem dodatkowej strony WWW pod hasłem „dla Rafała” wzbudziło zainteresowanie i przyczyniło się do przekazywania filmów kanałem wirusowym ${ }^{6}$.

W ostatniej kampanii samorządowej w Radomsku, w mieście leżącym w centralnej części Polski pomiędzy Częstochową a Łodzią z 50 tysiącami mieszkańców, kandydowało na fotel prezydenta sześciu mężczyzn i jedna kobieta. Prowadzili oni kampanie, stosując głównie narzędzia tradycyjne: spoty w telewizji, kampanię bezpośrednią, ulotki i plakaty. Jedynie dwóch kandydatów zrobiło krok dalej i użyło nowych mediów: Anna Milczanowska oraz Łukasz Więcek.

Warto jednak podkreślić, że pod koniec kampanii wyborczej ze względu na duże zainteresowanie tym co dzieje się w wirtualnym świecie, dostrzeżono rejestracje pozostałych kandydatów na Facebooku. Nie miało to już jednak znaczenia na wynik walki politycznej, lecz z pewnością podkreśliło wzrastającą rolę mediów społecznościowych.

1.1. Media społecznościowe w kampanii samorządowej w Radomsku na przykładzie kandydata na prezydenta - Anny Milczanowskiej

\section{Obecność na Facebooku}

Konto na tym serwisie społecznościowym pojawiło się wraz z rozpoczęciem oficjalnej kampanii. Zdaniem autorki to nieco za późno. Należało o tym pomyśleć parę miesięcy wcześniej, aby posiadać już pewną bazę znajomych i skupić się na prowadzeniu kampanii informacyjnej, a nie jedynie promować osobę. Serwis aktualizowany był systematycznie, początkowo jednym wpisem dziennie, zbliżając się do daty wyborów wpisy pojawiały się na tablicy trzy, cztery, a czasami pięć razy dziennie.

\footnotetext{
${ }^{6}$ http://www.dlarafala.pl/, 11.07.2011.
} 
Było to bardzo ważne, aby utrzymać zainteresowanie młodych wyborców i stale informować ich o programie. Warto podkreślić, że przekazywane treści często były zabawne i miały charakter ciekawych aplikacji. Zawsze nawiązywały do hasła RADOMSKO TAK i głównych tez programu wyborczego: TAK DLA OBWODNICY, TAK DLA ZDROWIA, TAK DLA KULTURY, TAK DLA INWESTYCJI. Przykładem tutaj może być zabawa w scrabble - na FB umieszczone były propozycje myśli związanych z wyżej wymienionymi hasłami. Komentarz do zabawy był następujący: Ja już powiedziałam swoje Tak dla miasta a Ty? Dołóż swoje hasło. Poniżej zdjęcie proponowanej zabawy.

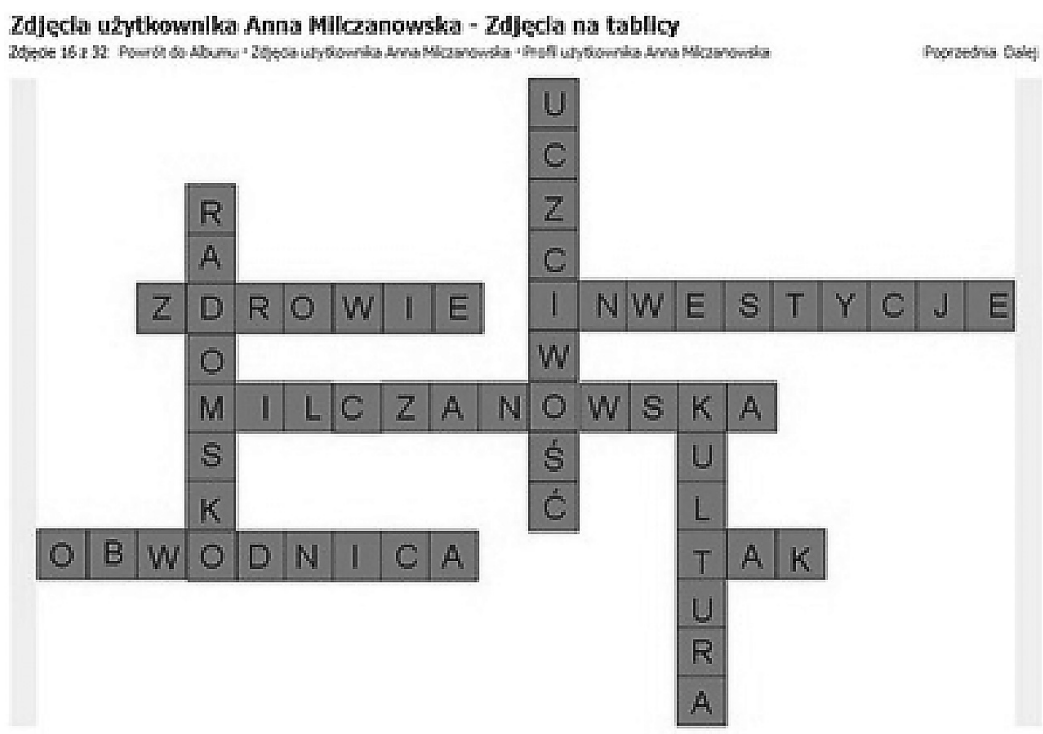

Zdjęcie 1. Tablica z Facebooka Anny Milczanowskiej

Źródı: facebook.com/anna.milczanowska, 20.06.2011 r.

Inną formą zabawy angażującej była aplikacja, umożliwiająca dodanie wpisu na osobistej tablicy użytkownika. Powodowało to, szerszą promocję oraz utożsamianie się z kandydatką i informowanie o tym swoich własnych przyjaciół. Tym razem wyborca miał odpowiedzieć, które TAK jest dla niego najważniejsze i dlaczego. Oprócz wpisu własnego był komentarz odgórny np. Tak dla Obwodnicy. Bo nie lubię korków nawet $w$ butelce. Tak dla Kultury. Bo nie tylko Chuck Norris może być gwiazda. Poniżej przedstawione zostało zdjęcie aplikacji. 


\section{RADOMSKO TAK!}

Radomsko potrzebuje rozsądnej kontynuacjl. Rzetelnej roboty zamiast obietnic. Ja jestem na taki TAK dla Radomika: dla inwestycji, programow spohecanych, bezpieczenistwa i zdrowia Radomszczan.

\section{...a Ty?}

KTORE "TAK" JEST DLA CIEBIE NA JWAŻNIEJSZE?

TAK DLA OBWODNICY

TAKDLA INWESTYCJI

TAK DLA KULTURY

TAK DLA ZDROWIA

Zdjęcie 2. Aplikacja na Facebooku

Źródło: facebook.com/anna.milczanowska, 20.06.2011 r.

Ponadto Facebook był miejscem informowania mieszkańców o programie i o tym co zostało realizowane przez ostatnie cztery lata sprawowania funkcji prezydenta. W tym celu posługiwano się specjalnymi ikonografikami, które w sposób wizualny trafiały do młodych odbiorców, ale nie tylko. W trakcie kampanii samorządowej w Radomsku FB okazał się istotnym źródłem komunikacji, ponieważ jeden z groźnych konkurentów (stosunkowo młody człowiek - w wieku 27 lat), był równie mocno osadzony na tym profilu społecznościowym oraz poszedł śladami europosła R. Trzaskowskiego, tworząc podobny serwis jak „dla Rafała”.

Profil Anny Milczanowskiej spełnił swoje oczekiwania. Liczba znajomych z dnia na dzień wzrastała. W dniu wyborów przekraczała już 200 osób, dziś sięga 900 znajomych. Wpisy były systematycznie komentowane lub wybierana była opcja „lubię to”. Początkowo profil na FB śle- 
dzili głównie przyjaciele i sympatycy, szybko jednak interaktywność wpisów i jego stała aktualizacja spowodowała zainteresowanie innych mieszkańców Radomska. Warto pamiętać, tworząc profil osoby znanej, aby utworzyć dodatkowo profil oficjalny, który bez zalogowania na FB może być śledzony. Pamiętajmy, że serwisy służą głównie jako kanał komunikacyjny z mieszkańcami, dlatego nie pozwólmy, aby ktoś kto nie ma ochoty zarejestrować się na FB, pozbawiony był możliwości otrzymania informacji. Oczywiście profil oficjalny można uzupełnić o konto prywatne z innymi opcjami. Pamiętać wówczas należy o tym, aby oba profile uaktualniać i uzupełniać.

\section{Obecność na YouTube}

Ważnym elementem kampanii wyborczej A. Milczanowskiej był kanał YouTube. Filmy na serwisie służyły do komunikacji wyborcom tego co kandydatka zrealizowała przez ostatnie cztery lata oraz co planuje na kolejną kadencję. W spotach wystapili jej koledzy ze stowarzyszenia mówiąc dlaczego Radomsko zasługuje na TAK i dlaczego popierają właśnie tą, a nie inną kandydatkę. Użycie w filmach znanych lokalnych twarzy wzbudziło zaufanie oraz informowało o dużym poparciu wśród mieszkańców, w tym młodych ludzi. Należy podkreślić, że spoty nie miały zabarwienia humorystycznego, ponieważ pełniły głównie rolę informacyjna.

Moim zdaniem możliwości tego profilu nie zostały w pełni wykorzystane. Niewątpliwie wzbogacenie strony internetowej, na której znajdował się opis programu wyborczego i inne ważne treści, o film, było doskonałym pomysłem. W ,społeczeństwie obrazkowym”, obywatele lubią przekaz multimedialny. Znacznie więcej osób obejrzy trzy minutowy film, niż przeczyta program.

Dobrze jest, kiedy film opowiada historię i każdy kolejny odcinek otwiera przed nami kawałek tajemnicy. Tutaj, jak w całej kampanii w internecie, liczy się przede wszystkim pomysł. Pamiętajmy jednak o tym - kto jest głównym odbiorcą treści w mediach społecznościowych i kto kandyduje. Nie zawsze pomysł pasuje do kandydata - poważnemu i ustabilizowanemu kandydatowi nie pasuje animowany film z obraźliwymi hasłami. Oczywiście od wszystkiego są wyjątki, to jest internet i tu nie ma sztywnych reguł. Czy najnowszy film zwolenników Palikota „Impreza u Tuska” nie odniósł zamierzonego efektu? 714 wyświetleń na 
5 godzin obecności w internecie to dobry wynik (w niedzielę 22 maja 2011 r. filmik obejrzało 89222 osób). Film, choć kontrowersyjny bawił i był przekazywany znajomym kanałem ,podaj dalej”. Być może dla polityków z pierwszych stron gazet, którzy zajmują ważne i szanowane funkcje w administracji państwowej czy ponadpaństwowej podobny film nie byłby wskazany. Czy jednak dla Palikota, który w swojej retoryce zawsze używa kontrowersyjnych treści i narzędzi, nie był dobrym pomysłem?

Są zwolennicy public relations, którzy uważają że tylko sukces się liczy i nie ważne jakie środki należy podjąć, aby go osiągnąć. Wszystko ma jednak swoją cenę. Moim zdaniem należy zawsze zastanowić się nad konsekwencjami, celem podejmowanych działań i rolą, jaką odegra ta internetowa grupy odbiorców w całej kampanii wyborczej - czy jest ona kluczowa i może wpłynąć na wynik, czy jedynie jest elementem wspomagającym całość działań.

\subsection{Strona internetowa}

Posiadanie własnej strony internetowej przez kandydata - już na każdym poziomie jest kluczowym narzędziem marketingu politycznego. Jest po prostu standardem w komunikacji politycznej, którego oczekują wyborcy. Jej rola jest ogromna, ponieważ jest szacunkowo tanim kanałem, który dostarcza informacji, zapewniając nadawcy pełną kontrolę nad treścią przekazu. Daje możliwość nieustannego aktualizowania publikowanych informacji oraz stałą i interaktywną komunikację z wieloma ludźmi. W pierwszej kolejności przy zakładaniu witryny należy pamiętać o czytelnej i jasnej domenie oraz celu, w jakim zostaje stworzona. Czy ma służyć budowaniu profesjonalnego wizerunku? Czy być może, ma być elementem kampanii wyborczej? W drugiej kolejności należy pamiętać o:

- wyglądzie - estetyce i spójności wizerunkowej;

- zawartości strony - o atrakcyjności strony decyduje nie tylko jej forma - ciekawy projekt graficzny czy zaawansowane funkcje. Liczy się przede wszystkim jej zawartość merytoryczna. Im jest ona bogatsza, tym większa grupa osób będzie z niej korzystać. To właśnie zawartość strony powinna zachęcać do kontaktu zwrotnego. Sekretem dobrej strony jest jej interaktywność, uzyskiwana dzięki dodawaniu takich elementów jak: sondy, ankiety, biuletyny, formularz kontaktowy. 
Ostatnio coraz powszechniejsza staje się możliwość współtworzenia strony, lub jej elementu np. redagowanie aktualności przez wielu użytkowników, a nie tylko jednego administratora;

- aktualności strony;

- funkcjonalności strony - korzystanie z całej zawartości musi być łatwe i szybkie. „Podstawową cechą funkcjonalnej strony jest logiczna nawigacja. Do projektowania witryn wykorzystuje się badania eye cracking, śledzenia ruchu gałki ocznej. Na ich podstawie można powiedzieć, że ruch gałki ocznej rysuje się na stronie w kształcie litery „F”. Internauta w pierwszej kolejności dostrzega lewy górny róg, następnie wodzi okiem wzdłuż lewej krawędzi strony w dół"7. Warto dodać, że dziś $80 \%$ stron opartych jest właśnie na jednym przyjętym standardzie projektowania. Dzięki temu internauta intuicyjnie wie, gdzie znajdują się poszczególne przyciski nawigacyjne ${ }^{8}$.

Strona internetowa kandydata na prezydenta A. Milczanowskiej, moim zdaniem, spełniła powyższe kryteria. Była bardzo prosta i funkcjonalna, utworzona na Wordpressie - serwisie, który umożliwia korelację i współpracę z innymi serwisami społecznościowymi. Niezwykle ważna była jej stała i systematyczna aktualizacja. Ogromną rolę odegrał także blog kandydatki - osobiste wpisy i przemyślenia, który współgrał ze stroną i był elementem aktualności. Na stronie znajdowała się także zakładka „zaangażuj się”, która informowała mieszkańców o tym jak można stać się częścią sztabu wyborczego - można było pobrać link i baner, aby umieścić go na swoich stronach w internecie, zostać przyjacielem na FB lub dołączyć do zespołów, dystrybucyjnych materiały promocyjne. Na stronie znajdowały się wszystkie niezbędne informacje dotyczące kandydatki i jej programu. Było to także miejsce podsumowania jej czteroletnich rządów oraz źródło wiedzy o tym, co dzieje się w kampanii wyborczej. Mocną stroną witryny był profil YouTube, który wyświetlał się po prawej stronie u góry. Uzupełniał on treści merytoryczne i wzbudzał zainteresowanie użytkowników.

Moim zdaniem na stronie zabrakło jednak centrum medialnego - materiałów gotowych do wykorzystania przez dziennikarzy: informacji, zdjęć czy życiorysu kandydata. Tutaj powinny zaleźć się także ulotki oraz skrócony program dla wyborcy - wszystko w plikach PDF. Nie było także

7 S. Trzeciak, Marketing Polityczny w Internecie, Warszawa 2010, s. 53.

8 Ibidem, s. 54. 
kalendarza, który jest zawsze cennym źródłem informacji o kampanii wyborczej dla wszystkich zainteresowanych działalnością danego polityka i ugrupowania. Kalendarz dla kandydata jest doskonałą formą promocji siebie jako osoby aktywnej i angażującej się w różne inicjatywy.

$\mathrm{Na}$ stronie powinna znaleźć się także zakładka z komitetem popierającym kandydata. Liczy się nie tylko poparcie liderów partyjnych, ale cenionych osób ze świata kultury, nauki i sportu. Lista „mocnych nazwisk" bardzo często przekłada się na dodatkowe głosy'.

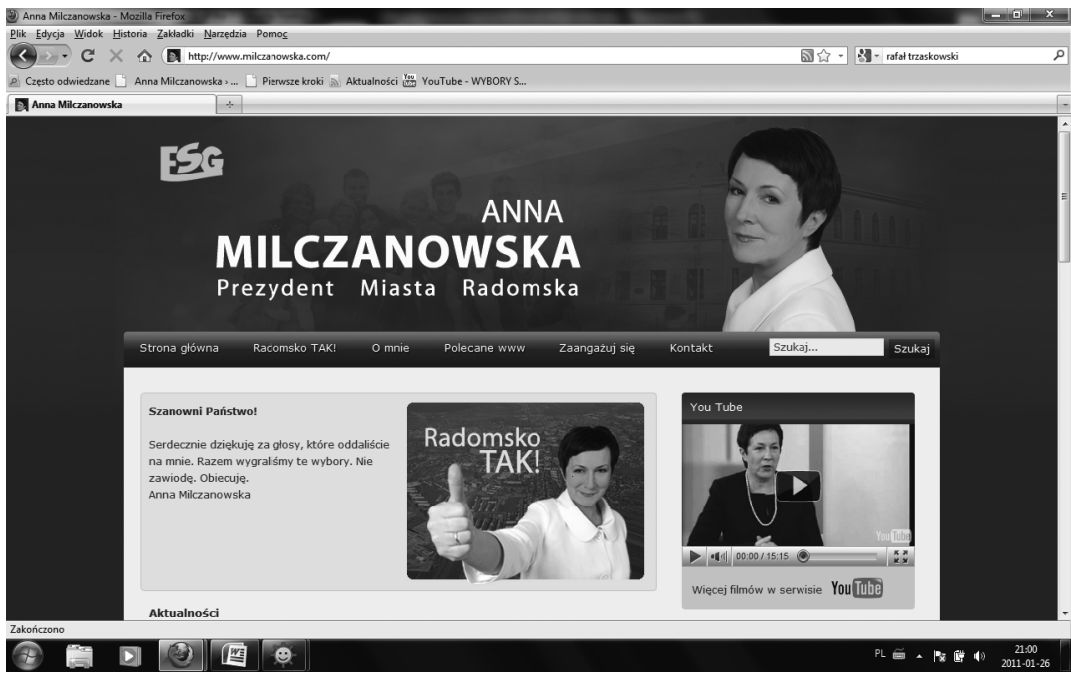

Zdjęcie 3. Strona internetowa kandydatki na Prezydenta Radomska Źródlo: www.milczanowska.com, 22.05.2011 r.

\section{Skuteczne zarządzanie informacją w mieście po wygranych wyborach}

Start w wyborach nie zaczyna się oficjalnym ogłoszeniem kampanii wyborczej, lecz z momentem objęcia fotelu prezydenckiego (przyjęciem mandatu). Pierwszy oficjalny dzień w Urzędzie Miasta jako prezydent, to pierwszy dzień kampanii wyborczej. Takie podejście do marketingu politycznego i strategii kampanii stawia przed osobami odpowiedzial-

9 Ibidem, s. 56. 
nymi za zarządzanie informacją w mieście wiele wymagań. Kreowanie pozytywnego wizerunku polityka, miasta to nie działania zadaniowe, prowadzone „od czasu do czasu”, lecz spójna strategia prowadzona codziennie. Dopiero zaplanowane i przemyślane działania z wykorzystanie wielu narzędzi może przynieść sukces.

\subsection{Facebook i Yotube}

Media społecznościowe powinny stać się częścią narzędzi wykorzystywanych do promocji. Profil miasta na FB jest doskonałym miejscem na przekazywanie informacji mniej formalnych - miejscem, gdzie buduje się zaangażowanie mieszkańców. Fan page miasta na FB daje możliwość pogłębiania relacji, buduje przywiązanie, lojalność, przyjaźń i miłość do miasta, z którym się utożsamia. Dzięki profilowi komunikacja z mieszkańcami staje się dwustronna, mniej inwazyjna. Web 2.0 umożliwia budowanie relacji, w której nie tylko dajemy, ale i bierzemy. Ważne jest, aby ta komunikacja nie opierała się jedynie na jednostronnej formie przekazywania informacji, które można odnaleźć w innych miejscach. Tutaj komunikacja musi mieć charakter konwersacyjny - tworzyć historię, dawać temat do rozmów. Wpis musi już od pierwszych słów intrygować i zachęcać, ponieważ użytkownicy czytają tylko kilka pierwszych słów. Powinien być uzupełniony także o zdjęcia i filmy ${ }^{10}$.

Angażować fanów marki możemy poprzez konkursy z nagrodami, quizy, sondy. Najczęściej są one tworzone w formie ciekawych zakładek, które wyświetlane są w lewym menu pod awatarem ${ }^{11}$.

Profil Radomska na FB ma 1158 fanów, jest aktualizowany codziennie. Największym zainteresowaniem cieszą się informacje dotyczące miasta - głównie ciekawostki, podparte zdjęciami. Fani nie lubią informacji linkowanych z innych portali. Na profilu brak konkursów, użytkownicy są jednak „spragnieni” większej interaktywności, czego dowodem są artykuły, które zachęcają do dyskusji na temat miasta. Trafionym pomysłem, ponieważ zostało „polubione” przez fanów, są zdjęcia dobrych artykułów z gazet lokalnych. Młodzi ludzie - główni użytkownicy FB, nie czytają lokalnych gazet,

10 P. Makuch, Jak wycisnać więcej z Facebooka, „Marketing w praktyce” 2011, nr 5 (159), s. 15.

${ }^{11}$ Ibidem, s. 14. 
stąd ich umieszczenie na profilu jest często jedyną szansą na przeczytanie tych informacji. Pamiętajmy jednak o tym, że wiadomości, które znajdują się na profilu powinny być neutralne i niezwiązane $\mathrm{z}$ opcją rządząca. Tutaj powinny znajdować się wszystkie cenne z perspektywy mieszkańca informacje. Jeśli w gazecie znajduje się artykuł, który negatywnie ocenia decyzję prezydenta, a jest ona ważna $\mathrm{z}$ jakiegoś punktu widzenia dla miasta - powinna znaleźć swoje miejsce na FB. W komentarzu możemy umieścić punkt widzenia prezydenta - zachęcając w ten sposób do polemiki.

Podsumowując: treści zamieszczane na fan page’u muszą być zaplanowane. Pamiętajmy, że użytkownicy poświęcają tylko 60 sekund na wszystko, co mamy im do powiedzenia. Jeśli ich zainteresujemy to mamy szansę zaistnieć na ich tablicy i rozpocząć codzienną komunikację ${ }^{12}$. Nie zasypujmy ich jednak zbędnymi informacjami, zastanówmy się jakie „wartości dodane” możemy lokalnej społeczności zaoferować. Nie mówimy tutaj o inwazyjnej, płatnej reklamie, ale o wartości, która sprawi, że członkowie społeczności staną się ambasadorami naszego profilu - miasta $\mathrm{w}$ internecie ${ }^{13}$. Czasami, jak już wyżej wspomniano, wystarczy ciekawa aplikacja lub konkurs. Ważne jednak, aby próba nawiązania relacji z odbiorcą była szczera i prawdziwa. To musi być autentyczny dialog.

\section{Profil Anny Milczanowskiej na Facebooku}

Po wygranej kampanii wyborczej należy kontynuować swoją obecność na profilu na Facebooku. Nie wskazane jest bowiem po czterech miesiącach aktywnej - bo codziennej komunikacji z fanami i znajomymi po prostu ich opuścić, pozostawiając bez możliwości kontaktowania się z osobą.

Profil jest idealnym miejscem do utrzymywania mniej formalnych więzi, podtrzymuje on kontakty, na które często w życiu nie ma czasu. Jest on doskonałym miejscem na dyskusję i polemikę z mieszkańcami miasta, na tematy kontrowersyjne. Tutaj można przekazywać informacje, na które nie ma miejsca w „oficjalnej polityce”, krytykować inne inicjatywy, pokazując swoje rozwiązania.

Stała i systematyczna komunikacja daje zaangażowanie oraz szansę na dotarcie z rzetelną informacją do większego grona wyborców. Przy

12 Ibidem, s. 18.

13 J. Gadzinowski, Era hiperkomunikacji, „Marketing w praktyce” 2009, nr 8 (138), s 40. 
prowadzeniu komunikacji za pomocą nowoczesnych narzędzi należy pamiętać o szybkim i regularnym odpowiadaniu na zamieszczone przez wyborców komentarze, pytania czy wiadomości. Pod żadnym pozorem nie można lekceważyć prób nawiązania kontaktu z mieszkańcami, obywatelami - osobami, które znajdują się po drugiej stronie i szukają odpowiedzi na nurtujące je pytania.

Pamiętajmy jednak, że interaktywność Facebooka niesie za sobą niezwykle duże ryzyko. Jako osoby publiczne dzięki niemu jesteśmy wystawieni na większą niż dotychczas ocenę. Jakikolwiek błąd ze strony włodarza miasta, może skończyć się negatywną agitacją na stronie FB. Nie powinno się wówczas tego lekceważyć ani usuwać wpisów. Należy szybko reagować i dyskutować. W komunikacji internetowej obowiązują jednak te same zasady co w tradycyjnych mediach. Na wypadek kryzysu kierujemy się podstawową zasadą ,przede wszystkim nie kłamiemy”. Dlatego jeśli popełniliśmy błąd, należy otwarcie zakomunikować o tym społeczności internetowej, najlepiej być pierwszym. W przypadku kryzysu osoby odpowiedzialne za komunikację powinny poinformować użytkowników o tym, co już zostało zrobione w tej sprawie, a co jest planowane.

\section{Radomsko na YouTube}

Obecność w tym kanale pozwala na ogromną promocję miasta i jego włodarza. Marketing na YouTubie i Facebooku łączy zalety reklamy telewizyjnej, takie jak przede wszystkim dostarczanie rozrywki i informacji wywołującej pozytywne reakcje emocjonalne, z interaktywnością, charakterystyczną dla internetu. YouTube jest dziś kluczowym kanałem komunikacyjnym, wpływa na to przede wszystkim jego atrakcyjność pod względem dotarcia, ale także możliwości kreatywnego podejścia i wykorzystania zjawiska marketingu wirusowego ${ }^{14}$. „W każdej minucie do serwisu YouTube trafia 20 godzin materiału filmowego - zarówno od samych internautów, jak i reklamodawców, producentów filmowych, wytwórni muzycznych czy stacji telewizyjnych. Aby oddać skalę tego procesu, wystarczy wyobrazić sobie, że gdyby wyemitować w telewizji materiał dodany w ciągu 60 dni na YT, potrzeba by było czterech kanałów nadających 24 godziny na dobę"15.

14 A. Kwaśniewski, YouTube marketing, „Marketing w praktyce” 2010, nr 1 (143), s. 3 .

${ }^{15}$ Ibidem, s. 2. 


\subsection{Biuro prasowe}

Działania public relations oraz polityka informacyjna odgrywają jedną z podstawowych ról w administracji. Zadaniem, - a właściwie obowiązkiem urzędu jest nie tylko informowanie odbiorców - społeczność lokalną - o swoich działaniach, ale także reprezentowanie publicznych interesów oraz niwelowanie potencjalnych konfliktów. Niejednokrotnie właściwe zarządzanie informacją zależy od tego miejsca.

Biuro powinno być podporządkowane bezpośrednio prezydentowi, mając całkowitą odpowiedzialność za komunikację zewnętrzną. W praktyce sprowadza się to do odcięcia innych jednostek w urzędzie od działań informacyjnych oraz wykonywania zadań, w których kompetentne jest biuro prasowe i PR. Prezydent jedynie zobowiązuje poszczególne działy do wspomagania biura $\mathrm{w}$ informowaniu obywateli i zainteresowanych stron oraz w działaniach PR.

Urząd Miasta Radomsko prowadzi politykę symetryczną i dwustronną. Oznacza to, że zadaniem komunikacji jest szukanie obustronnego zrozumienia poprzez dialog $\mathrm{w}$ celu zgodności z opinią publiczną. W ramach kontaktów z mediami (media relations) najbardziej popularnymi sposobami komunikacji są: konferencje prasowe, rozsyłanie informacji prasowych czy wywiady dla mediów. Komunikacja poprzez internet i pocztę elektroniczną jest prowadzona $\mathrm{z}$ wykorzystaniem strony internetowej urzędu i kandydata, profilu na Facebooku i YouTube, strony Biuletynu Informacji Publicznej, mailingu.

W najbliższym czasie planowane jest wdrożenie bardziej nowoczesnych kanałów i sposobów rozsyłania komunikatów prasowych z Radomska. Ciekawym sposobem może być wysyłanie wiadomości za pomocą Facebooka. Warto tutaj wyszukać innych niż lokalnych reporterów. Nawet jeśli nie jesteśmy z nimi „przyjaciółmi”, możemy wysłać krótką informację, ze zdjęciem i linkiem do treści na witrynie głównej miasta. Do podobnych celów można zastosować inne komunikatory. Według badania przeprowadzonego przez polski oddział agencji public relations LEVIS i portal PRoto.pl Czy tradycyjna notatka prasowa ustapi miejsca mikrokomunikatom w Internecie?, okazało się, że wzrasta rola nowych mediów - Skype i Gadu Gadu (55 proc. respondentów) $)^{16}$.

16 www.pusto.pl. 


\section{Podsumowanie}

Kończąc śmiało można stwierdzić, że nowe media będą odgrywać ogromną rolę w polityce informacyjnej polityków i organów rządowych czy samorządowych. Nowa komunikacja, której niewątpliwie największą zaletą jest jej interaktywność, wymaga od nadawcy niezwykłej świadomości i rzetelności. Należy pamiętać, że każda próba nawiązania relacji z odbiorcą komunikatu musi być autentyczna. Korzystanie z wymienionych $\mathrm{w}$ tej pracy narzędzi oznacza przejście na zupełnie nowy poziom, który wystawia efekty pracy na większą niż dotychczas ocenę opinii publicznej.

Użytkownicy Facebooka, YouTube traktują te źródła jako wiarygodne i niezwykle użyteczne, natomiast dziennikarze szukają informacji i inspiracji na blogach, blibach i innych komunikatorach. Dlatego pozwólmy, aby treści dotyczące życia społecznego znalazły tu swoje zacne miejsce.

Nie należy jednak zapominać, że działania PR w urzędach, uwzględniające nowe trendy i narzędzia powinny być zgodne ze standardami nowoczesnego państwa, czyli m.in. otwartością, uczciwością i profesjonalizmem. Takie podejście jest korzystne dla ogółu obywateli, którzy bardziej oczekują od urzędów kulturalnej, fachowej i sprawnej obsługi niż kreowania wizerunku superurzędu, odbiegającego od rzeczywistego sposobu jego funkcjonowania. PR powinien być postrzegany nie jako szybko działające narzędzie do zdobywania poparcia społecznego, ale jako sztuka długotrwałego budowania relacji z otoczeniem, dobrej dwustronnej komunikacji.

\section{Bibliografia}

\section{Monografie:}

Janiszewska B., Sztuka public relations. $Z$ doświadczeń polskich praktyków, wyd. Związek Firm Public Relations, Warszawa 2006.

Meerman Scott D., Nowe zasady marketingu i PR, wyd. Wolters Kluwer Polska Sp. z o.o., Warszawa 2009.

Pluta E., Public relations, moda czy konieczność, teoria i praktyka, wyd. Twigger, Warszawa 2001.

Levine M., Partyzanckie Public Relations w Interncie, wyd. PLACET, Warszawa 2003.

Trzeciak S., Marketing polityczny w internecie, Warszawa 2010. 


\section{Prasa:}

Kwaśniewski A., YouTube marketing, „Marketing w praktyce” 2010, nr 1 (143).

Górecka A., Dołacz do społeczności, „Marketing w praktyce” 2009, nr 8 (138).

Trzeciak D., Blogopedia inspiracji, „Marketing w praktyce” 2009, nr 8 (138).

Rzepecki J., Hankus-Matuszek G., Wymagajacy użytkownik - bezcenny, „Marketing w praktyce" 2009, nr 8 (138).

Gadzinowski J., Era hiperkomunikacji, „Marketing w praktyce” 2009, nr 8 (138).

Klimowicz M., Web 2.0 to nie młotek!, „Marketing w praktyce” 2009, nr 8 (138).

Gajowniczek M., Internet liderem, „Marketing w praktyce” 2009, nr 8 (138).

Rosłan M., Facebook prawdę ci powie, „Marketing w praktyce” 2009, nr 8 (138).

Zawadzki M., Postawić na blogi?, „Marketing w praktyce:, sierpie2009, nr 8 (138).

Krauscher P., Marka z własnq telewizja, „Marketing w praktyce” 2010, nr 09 (151).

Makuch P., Jak wycisnać więcej z Facebooka, „Marketing w praktyce” 2011, nr 5 (159).

\section{Źródla internetowe:}

www.milczanowska.com - strona kandydatki na prezydenta Radomska Anny Milczanowskiej.

www.barackobama.com - strona internetowa Baracka Obamy.

www.rafaltrzaskowski.pl - strona kandydata na posła PE Rafała Trzaskowskiego.

www.dlarafała.pl - strona fanów kandydata na posła PE Rafała Trzaskowskiego.

\section{An election campaign in a mayor's office - efficient methods of managing information in town}

\section{Summary}

The paper discusses the role new media play in the information policy of a politician running for office based on the example of the campaign run by the candidate for the office of president of Radomsko, Anna Milczanowska. As the Internet is becoming increasingly influential and the interest in social platforms increases, the assumptions of PR activities have changed. The paper emphasizes that at present the senders of a message do not require traditional media to reach the recipient. It demonstrates that the proverbial 'single click' of a mouse is sufficient to notify thousands about the sender's activities. This thoroughly changes the position of PR officers, as one-way communication has been replaced by a two-way dialogue once and for all. Local authorities have obtained a new tool which on the one hand facilitates genuine contact, but on the other, subjects them to a greater degree of social assessment. 